\title{
New records of Humiriaceae fossil fruits from the Oligocene and Early Miocene of the western Azuero Peninsula, Panamá
}

\author{
Nicolas Pérez-Consuegra, Daniel E. Góngora, Fabiany Herrera, Carlos Jaramillo, Camilo Montes,
} Aura M. Guervo-Gómez, Austin Hendy, Alejandro Machado, Damian Gárdenas, German Bayona

Nicolas Pérez-Consuegra

nperezco@syredu

Department of Earth Sciences, Syracuse University, Syracuse, New York 13244, USA. Smithsonian Tropical Research Institute, Balboa, Ancón, Panamá.

Daniel E. Góngora

Aura M. Cuervo-Gómez

Departamento de Geociencias, Universidad de los Andes, Carrera 1 No. 18A-12, Bogotá, Colombia.

\section{Fabiany Herrera}

Chicago Botanic Garden, 1000 Lake Cook Road, Glencoe, Illinois 60022, USA.

\section{Carlos Jaramillo}

Alejandro Machado

Damian Cárdenas

Smithsonian Tropical Research Institute,

Balboa, Ancón, Panamá.

\section{Gamilo Montes}

Geology, Universidad del Norte, Km. 5 Vía Puerto Colombia, Barranquilla, Colombia. Departamento de Geociencias, Universidad de los Andes, Carrera 1 No. 18A-12, Bogotá, Colombia.

\section{Austin Hendy}

History Museum of Los Angeles County, Los Angeles, CA 90007, USA.

\section{German Bayona}

Corporación Geológica ARES, Bogotá, Colombia.

\begin{abstract}
Understanding the origin of the diversity in Central American forests requires the integration of both extant and fossil taxa. Here, we provide a description of Humiriaceae fossils from two new sedimentary sequences in the Azuero Peninsula, Panamá. Fossils were recovered from Oligocene (one locality) and Early Miocene (two localities) marginal marine deposits. We describe new specimens and augment the generic description of Lacunofructus cuatrecasana Herrera, Manchester et Jaramillo, and present a new record of Sacoglottis sp. Our results expand the temporal and geographical distribution of both taxa and show that Humiriaceae was an important constituent of early Central American forests, and that this family was dispersed in between Central and South America before the final closure of the Central American Seaway. Further studies are necessary to establish whether the origin of this family was in Central or South America.
\end{abstract}

Keywords: Central America, fossil endocarps, Lacunofructus, Neotropical forests, Isthmus of Panama, Sacoglottis.
BOL. SOC. GEOL. MEX. 2018

VOL. 70 NO. 1

P. $223-239$

http://dx.doi.org/10.18268/BSGM2018v70nla13

\section{RESUMEN}

Para entender el origen de la diversidad de los bosques de América Central, se necesita integrar estudios de plantas actuales y fósiles. En este trabajo, describimos fósiles de Humiriaceae, excavados de dos nuevas secuencias sedimentarias en la Península de Azuero, Panamá. Los fósiles fueron encontrados en depósitos marinos-marginales del Oligoceno (una localidad) y del Mioceno temprano (dos localidades). Describimos nuevos especimenes y aumentamos la descripción morfológica de Lacunofructus cuatrecasana Herrera, Manchester et Faramillo para las localidades del Oligoceno y Mioceno temprano y presentamos un nuevo registro de Sacoglottis sp., para el Mioceno temprano. Estos nuevos registros expanden los rangos de distribución geográfica y temporal para ambos taxones, y además demuestran que la familia Humiriaceae fue un importante constituyente de los primeros bosques en América Central. La evidencia presentada también sugiere que hubo dispersiones de especies de Humiriaceae entre Centro y Sur América mucho antes del cierre del Istmo de Panamá. Se necesitan más estudios para establecer con claridad si el origen de Humiriaceae se dio en América Central o Sur América.

Palabras clave: América Central, endocarpos fósiles, Lacunofructus, bosques Neotropicales, Istmo de Panamá, Sacoglottis. 


\section{Introduction}

Southern Central America (i.e., Panamá and Costa Rica) is one of the regions with the highest extant angiosperm diversity in the world (Barthlott et al., 1996). This plant diversity flourishes in varied forest types that grow over a complex geologic landscape. The emergence of the Isthmus of Panamá started during the Eocene (Herrera et al., 2012; Montes et al., 2015, 2012a, 2012b; Jaramillo, 2016; O'Dea et al., 2016; Jaramillo et al., 2017); thus, this region provides an excellent opportunity to understand how the tropical vegetation of a newly created land evolved in relation to tectonic and climatic changes over time (Jaramillo et al., 2014; Jaramillo, 2016). Paleofloras of peninsular Central America during the Cenozoic are important for reconstructing the exchange of plant species between Central America and South America (Jaramillo et al., 2014; Bacon et al., 2015) and also for understanding paleoenvironmental changes (Jud and Dunham, 2017).

Most paleobotanical studies about floristic composition in Central America came from palynological analyses (i.e., fossil pollen and spores) (Burnham and Graham, 1999; Jaramillo et al., 2014). Recent reports have shown that by the Early Miocene, Panamanian forests were already dominated by Gondwanan-Amazonian taxa, suggesting that long-distance dispersal across the Central America seaway occurred much earlier than previously suggested (Jaramillo et al., 2014; Bacon et al., 2015). The palynological record is important for reconstructing the paleocommunities in Panamá (Jaramillo et al., 2014); however, this record is limited given the relatively low taxonomic resolution that the pollen offers for the identification of plants. Plant macrofossils (e.g., fruits, leaves, and wood) in Central America are necessary to better understand the dispersal and evolution of particular plant groups. In recent years, excavations along the Panamá Canal, Lake Alalajuela and Azuero Peninsula have allowed the discovery of various Cenozoic localities with abundant fruits, seeds, leaves, and wood from several families; for exam- ple Humiriaceae, Juglandaceae, Malvaceae, Calophyllaceae, Connaraceae and Chrysobalanacea (Herrera et al., 2010, 2012, 2014a, 2014b; Carvalho et al., 2013; Rodríguez-Reyes et al., 2014, 2017; Jud et al., 2016; Jud and Nelson, 2017; MacFadden et al., 2017; Nelson and Jud, 2017).

We report new permineralized and carbonized fossil endocarps and seeds of Humiriaceae from three new localities on the Pacific coast of Panamá, near the town of Torio, province of Veraguas (Figure 1). The fossils were recovered both from Oligocene (1 locality) and Early Miocene (2 localities) marginal marine deposits (figures 1 and 2). We describe these specimens and augment the generic diagnosis of Lacunofrucutus cuatrecasana Herrera, Manchester et Jaramillo, and present a new record of Sacoglottis sp. We also provide a sedimentological description and a biostratigraphic analysis based on fossil mollusks, calcareous nannoplankton, and palynology for each of these localities.

\subsection{HUMIRIAGEAE FAMILY}

Extant Humiriaceae includes eight genera of mostly woody, evergreen plants (Cuatrecasas, 1961; Kubitzki, 2014). Trees in this family range from tall canopy trees to medium sized shrubs (Kubitzki, 2014). Humiriaceae are typical members of the rainforests, but are also found in savannahs up to an elevation of $1400 \mathrm{~m}$ (Kubitzki, 2014). The geographic distribution of the family is predominantly Neotropical with $\sim 50$ species, with the exception of the species Sacoglottis gabonensis (Baill.) Urb. that grows in the west African tropics (Herrera et al., 2010; Kubitzki, 2014).

Humiriaceae fossil endocarps and wood remains are some of the most common elements of the Eocene to Pleistocene floras of Central America (Herrera et al., 2010, 2012, 2014b; Lott et al., 2011; Jud and Dunham, 2017), which show that this group has been present in the region since the land started to emerge in the Eocene (Herrera et al., 2012; Montes et al., 2012b). Eocene Panamanian fossils (Herrera et al., 2012) are also the oldest record of the Humiriaceae family, suggesting a Neotropical origin, but it is not clear whether 
the center of origin was Central America or South America.

Fossil endocarps, wood and pollen of Humiriaceae are also relatively common in Eocene - Pliocene sedimentary rocks of northern South America (Berry, 1924; Wijninga, 1996a, 1996b; Manchester et al., 2012). By the Early Miocene, this family was widely distributed in the Neotropics (Herrera et al., 2010, 2012, 2014b). However, it is not clear whether Humiriaceae had a single dispersal event, or there were multiple dispersal events across the Central American Seaway between Central and South America. Previous studies on other Neotropical families have found evidence of diversification after long-distance dispersal events (e.g, Chrysobalanaceae; Bardon et al., 2013; Jud et al., 2016).

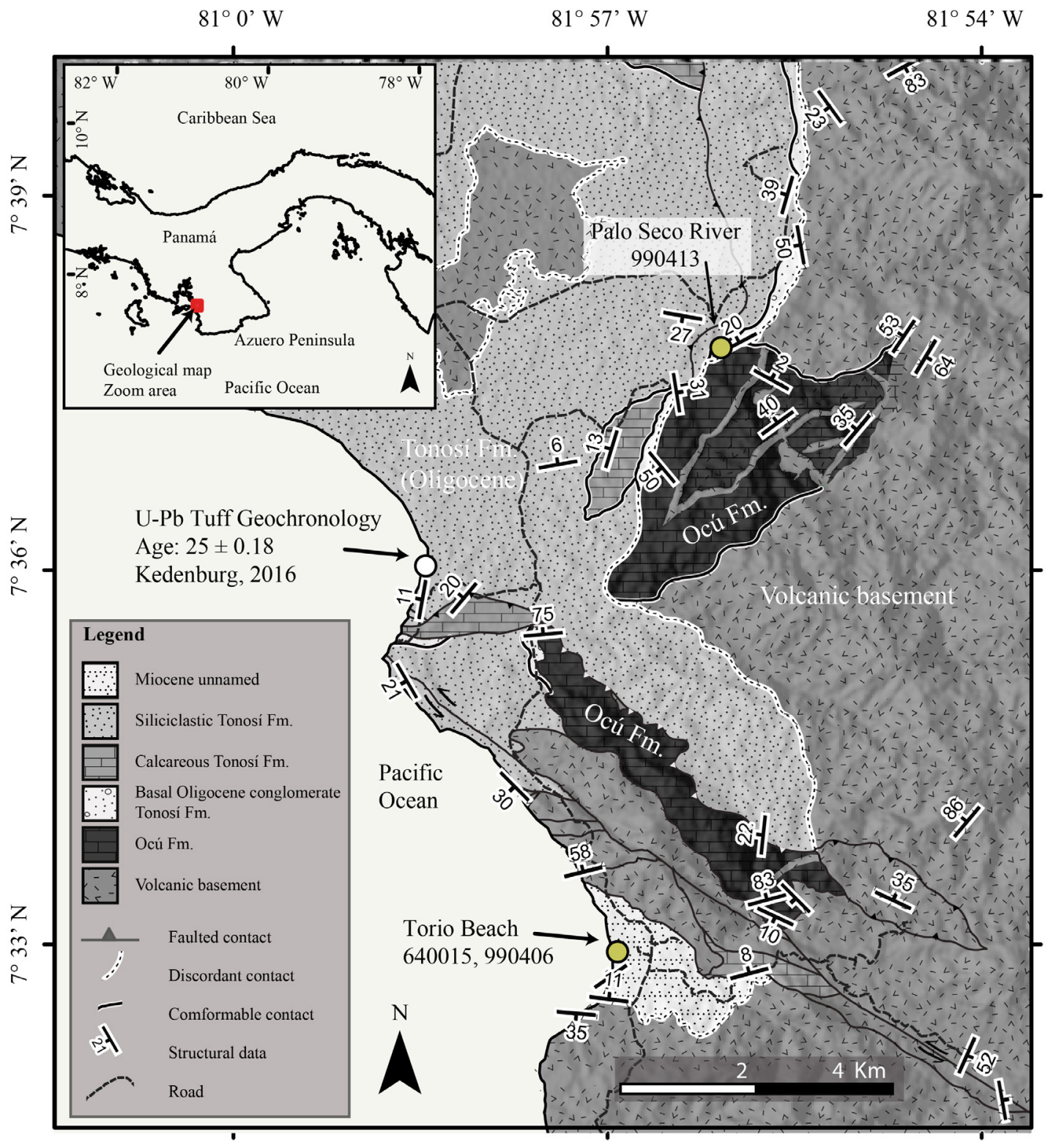


Palo Seco river

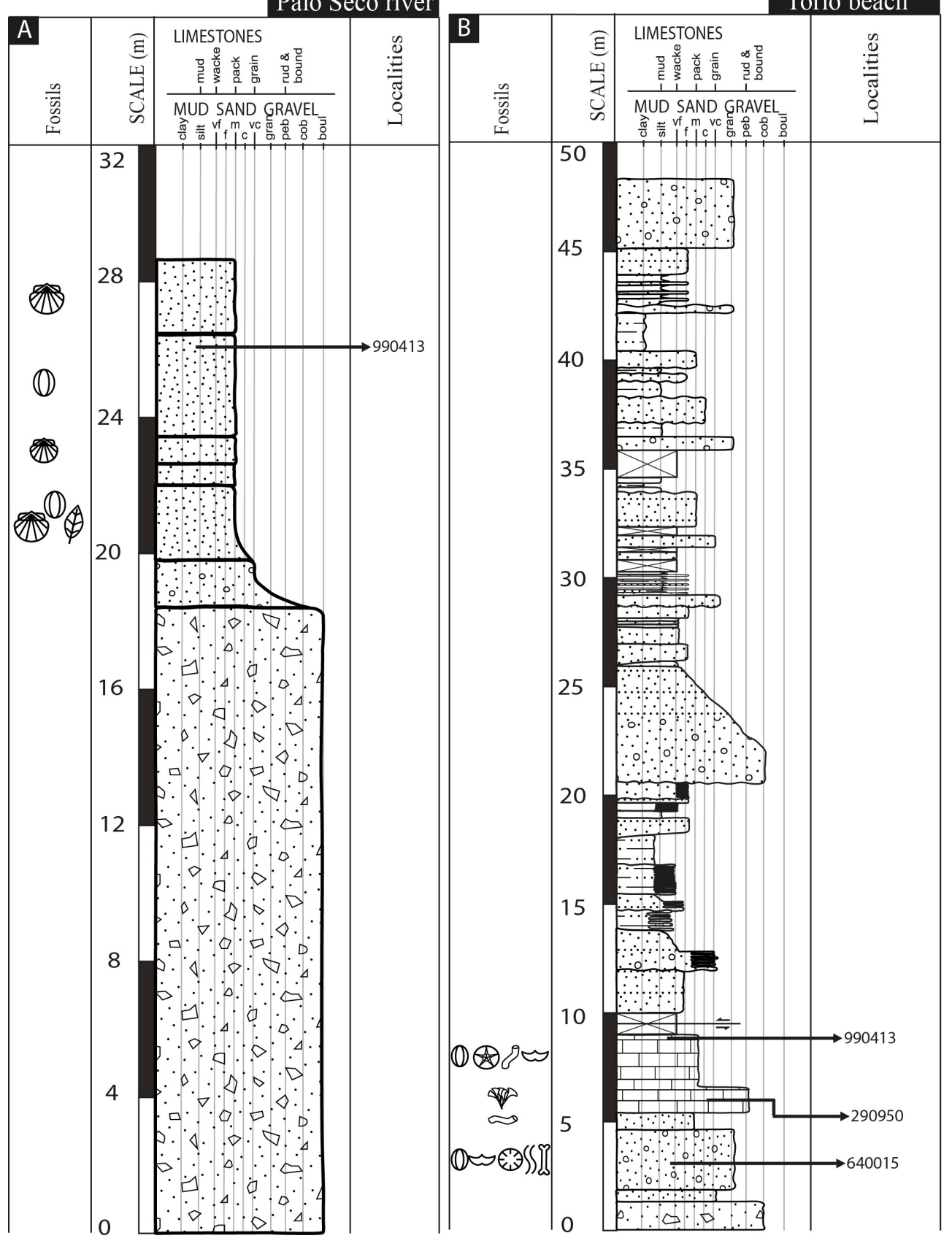

Legend:

Carbonates

$\bullet \cdot$ Angular

Breccia

$\because \because 0$ Conglomerate

$\therefore \quad$ Very fine to very coarse sandstone

$\therefore$ Very fine to very coarse sandstone with horizontal lamination

$\cdots \cdot \cdot$... Mudstones

$\varepsilon=3$ Vertebrates

(2) Echinoderms

Mollusks

(1) Seeds

$\iint$ Burrows

से Corals

(56) Algae

(9) Talassinoids

$\mp$ Shells

Leaves

Figure 2 Stratigraphic columns of the studied sedimentary sequences in the Palo Seco River (A, Oligocene) and Torio Beach (B, Early Miocene) showing the fossil horizons and sample localities.

\subsection{GEOLOGY OF THE AZUERO PENINSULA}

The general geology of the Azuero Peninsula has been described as a diverse igneous basement overlaid by forearc sediments (Buchs et al., 2011). The forearc sediments include turbidites, shallow marine limestone, and fluvially influenced siliciclastic facies that were deposited in the Eocene - Miocene and have been subdivided into the Covachón, Tonosi and Santiago formations (Kolarsky et al., 1995; Buchs et al., 2011). 
The sedimentary sequences that crop out in the northwestern Azuero Peninsula (near Torio) have been assigned to the Tonosi formation, which has been dated as Eocene - Early Miocene based on calcareous nannofossils (Kolarsky et al., 1995). Recent geological mapping of the vicinities of the town of Torio allow us to identify two different sedimentary units: (1) an Oligocene sedimentary unit that unconformably overlies the Campanian - Paleogene Ocú formation in the Palo Seco River tributary and extends to the north of Torio (Figure 1), and (2) an Early Miocene sedimentary unit that overlays the Azuero proto arc (volcanic basement) group in the Torio Beach outcrops (Figure 1).

\section{Materials and Methods}

The fossil floras were found near the town of Torio in the western part of the Azuero Peninsula, Panamá; Smithsonian Tropical Research Institute (STRI) localities 640015: 7.54510 N, -80.95070 W (Early Miocene); STRI 990406: $7.54500 \mathrm{~N}$, -80.94980 W (Early Miocene); and STRI 990413: $7.63920 \mathrm{~N},-80.93310 \mathrm{~W}$ (Oligocene). The first two localities crop out at the beach near the town of Torio (Torio Beach; figures 1 and 2), and the third locality crops out in a small tributary creek of the Palo Seco River (figures 1 and 2). The fossil specimens are housed at the Florida Museum of Natural History (FLMNH). Information on the locality and samples can be accessed at the STRI PaleoDatabase (http://biogeodb.stri.si.edu/jaram illosdb/web/login).

Toreveal and describe the internal anatomy of the fossils, sections were cut through the base, equator, and apex, with a low speed, thin-bladed diamond saw. The specimens were photographed with a Nikon D90 digital camera and with a Nikon DXM 1200C stereoscope (Figure 3). Acetate peels of the fossils were prepared using standard techniques (Joy et al., 1956; Herrera et al., 2012). Specimens were polished using silicon carbide grit (600) and then etched in diluted $(5 \%) \mathrm{HCl}$ for five seconds. Specimens were then washed with water and sub- sequently dried. The etched surface was covered with acetone and a portion of cellulose acetate was placed over the surface. The specimens were dried with air and then the acetate was removed manually to generate the acetate peels. The peels were mounted in microscope glass slides with Canada balsam mounting medium.

We compared the fossils with fruits from extant species housed at the herbarium of the Smithsonian Tropical Research Institute (SCZ). Fruit characters of Humiriaceae were selected according to previous nomenclature and descriptions of the family (Cuatrecasas, 1961; Herrera et al., 2010, 2012, 2014b; Kubitzki, 2014); however, we also added new terminology for the description of the fossil embryos. We selected three extant species of Humiriaceae from Panamanian forests, available at the SCZ, for anatomical comparisons: Sacoglottis ovicarpa Cuatrec., Humiriastrum diguense (Cuatrec.) Cuatrec. and Vantanea depleta McPherson. In addition, we examined sections of the modern endocarps using the same methodology as for the fossil endocarps (Figure 4). The fossil and extant specimens and the sections were observed under a light microscope (10x, 20x and 40x), stereoscope, and a Nikon research E600 fluorescence microscope for the identification of specific cellular structures of the endocarp, endosperm, cotyledons, and hypocotyl.

\subsection{STRATIGRAPHY AND SEDIMENTOLOGY}

We measured two stratigraphic sections at a 1:50 scale with a Jacob's staff, at the base of both the Early Miocene and Oligocene sedimentary units (Figure 2), to include the strata where the fossils were found (Figure 2).

\subsection{MIGROPALEONTOLOGICAL ANALYSES}

One sample for calcareous nannoplankton and palynology analyses was collected from each of the three fossil localities (Figure 2). For calcareous nannoplankton analysis, two grams of sediment were extracted from each sample and mounted on glass slides. Subsequently, the sediment was 


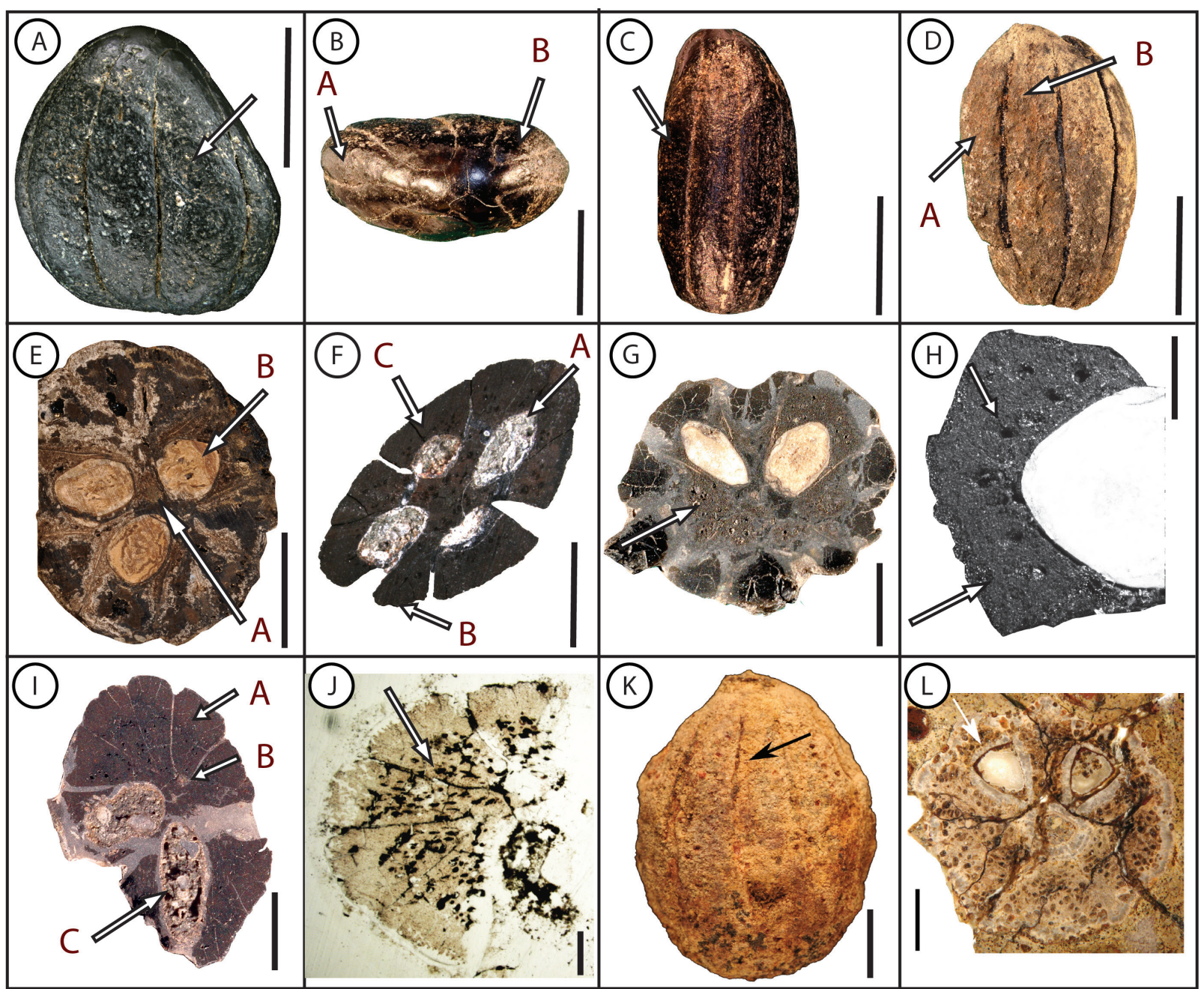

Figure 3 A - H, Lacunofructus cuatrecasana from the western Azuero Peninsula.

A - C, Specimen FMNH 68983-STRI38784 (Oligocene).

A, Dorsal view of the endocarp showing germination valves (arrow).

B, Apical view of the endocarp showing septae (arrow A) and germination valves (arrow B).

$C$, Lateral view of the endocarp showing germination valves (arrow).

D, Specimen FMNH 68984-STRI40032 (Oligocene). Dorsal view of the endocarp showing germination septae (arrow A) and germination valves (arrow B). The variation in endocarp shape within specimens is caused by diagenetic deformation.

E, Specimen FMNH 68982-STRI40060 (Early Miocene). Transverse section of medial part of the endocarp showing central vascular bundle (arrow A), three seeds (arrow B), three septae, and three germination valves.

F, Specimen FMNH 68981-STRI40052 (Early Miocene). Transverse section of the upper half of the endocarp, showing four seed locules (arrow A), four septae (arrow B), and four germination valves (arrow C). Lacunae (cavities) are visible within the endocarp (lower red arrow).

G - H, Specimen FMNH 68987-STRI40033 (Early Miocene).

G, Transverse section of medial part of the endocarp showing two seeds and two germination valves.

$\mathrm{H}$, Detail of germination valve and seed of 1-G. Lacunae are clearly visible in the endocarp (white arrow).

I - J, Specimen FMNH 68986-STRI40034 (Early Miocene).

I, Transverse section of medial part of the endocarp showing two seeds, five septae, and five germination valves (arrow), three of which have aborted seeds (arrow) and 2 seed locules filled with sediment (arrow).

J, Acetate peel of 1-I showing abundant lacunae (red arrow) on endocarp wall (i.e., septae and germination valves).

K - L, Lacunofructus cuatrecasana from the eastern Azuero Peninsula, Tonosi Fm (Herrera et al., 2012).

$\mathrm{K}$, Lateral view of endocarp, the arrow shows a furrow that corresponds to the exterior lingulate germination valve.

$\mathrm{L}$, Thin section of endocarp showing abundant lacunae and two well-developed seeds, one indicated by the arrow.

Scale bar: A - G, I: 5 mm; H, J: 1 mm. 
crushed against the glass with the aid of a needle and distilled water sufficient for processing, usually $2-3$ drops, then the slides were dried on a hot plate $(\sim 40 \mathrm{C})$. A glass cover was mounted on the slide with the aid of Canada balsam mounting medium. The slides were observed under a polarized light microscope. For the taxonomic identification of calcareous nannoplankton and the determination of the stratigraphic ranges, we used the parameters proposed by Bown (1998) and Bolli et al. (1989). We follow the Neogene zonation of Martini and Worsley (Martini, 1971), and the Geological Time Scale 2012 (Gradstein et al., 2012). For palynological analysis, three samples were prepared following the standard palynological procedure (Traverse, 2007) and were done at Paleoflora, Inc. (Bucaramanga, Colombia).

\section{Results}

\subsection{STRATIGRAPHY AND SEDIMENTOLOGY}

The stratigraphic sequence of the Palo Seco River measures $29 \mathrm{~m}$ (Figure 2A). It is composed of a massive polymictic (e.g., chert, basalt, and other igneous rocks) breccia near the base (Figure 2A). The sequence transitions to intercalations of calcareous sublitharenites with abundant marine fossil material (e.g., mollusks) to sublitharenites with more fluvial transported material (e.g., leaves, seeds and wood) but still with traces of foraminifera. Several horizons within the Palo Seco River succession contained fossil endocarps; however, all the fossils were excavated from a sandstone layer from 23.5 to $26.5 \mathrm{~m}$ (Figure 2A).

The stratigraphic section of the Torio Beach deposits measures $48 \mathrm{~m}$ (Figure 2B). It is composed of a massive breccia at the base with polymictic composition (e.g., chert and basalt). The sequence transitions from the basal breccia to conglomeratic sandstones. These layers are overlayed by a conglomeratic stratum (meter 7.5 - 9) that contains the fossil endocarp locality (STRI 990413). This fossiliferous layer also contains vertebrate bone fragments (dugong), fish teeth, and ex-situ corals.
This stratum is overlain by a massive-bioturbated layer (meters $2-4.5$ ) of sandy conglomerates with horizontal burrows (STRI 640015) and numerous fossils of mollusks, crab fragments, cirripedia, and wood. The mollusks include Leopecten sp.,Crassostrea sp., Ampullinopsis spenceri, Galeodea sp., and Ficus cf. F. carbasea. On top of this basal sequence, there are calcareous algal beds and fossiliferous limestones (STRI 290950; meters 5.5 - 7.5) containing abundant Thalassinoides burrows, spatangoid echinoderms, raninid crabs, and gastropod fossils of Naticidae, Muricidae, Antillophos aff. A. gatunensis, Conus sp., and Turridae (Figure 2B). On top of these fossiliferous levels, a fault separates a second sequence of $\sim 38 \mathrm{~m}$ of predominantly clastic strata (Figure 2). The base of this sequence is composed of mudstones. The intermediate meters are comprised of a massive conglomerate bed, and fine- to medium-grained sandstone interbedded with coarse- to very coarse-grained sandstone and minor mudstones beds. At the top, there are fineto medium-grained sandstones, mudstones and conglomerates.

\subsection{AGE OF THE DEPOSITS}

A sample from locality STRI 990413 collected from the Palo Seco River did not contain nannofossils. However, this sample has good recovery of terrestrial organic matter, mainly phytoclasts with low abundances of pollen and spore grains, and dinoflagellate cysts. The palynological assemblage is characterized by the dinoflagellate cysts Achomosphaera alcicornu, Polysphaeridium zoharyi, Spiniferites ramosus, the pollen grain Perisyncolporites pokornyi, and the spores Concavissimisporites fossulatus and Striatriletes saccolomoides. Based on the first appearance datum of $A$. alcicornu in equatorial latitudes this sample must be younger than $33.76 \mathrm{Ma}$ (Williams et al., 2004). Based on the palynology and on the $25.1 \pm 0.18 \mathrm{Ma}$ age (zircon $\mathrm{U}-\mathrm{Pb}$ geochronology; Kedenburg, 2016) of a tuff on the top of this sedimentary sequence (Figure 1) we assign an Oligocene age to this unit.

Samples from locality STRI 640015 from the Torio Beach contained several nannofossils in- 
cluding Reticulofenestra minuta and $R$. pseudoumbilicus. The sample of locality STRI 990406 also from the Torio Beach contained the nannofossils: Cyclicargolithus floridanus, Discoaster deflandrei and R. pseudoumbilicus. Based on the presence of $R$. pseudoumbilicus samples cannot be older than NN4, and together with $C$. floridanus and $D$. deflandrei the sample is not younger than NN7. The age of the Torio Beach sedimentary sequence is between NN4 to NN7, late Early Miocene to early Late Miocene (Burdigalian to Tortonian).

Palynological samples from locality STRI 990406 and locality STRI 640015 yielded a good recovery of well-preserved palynomorphs. Organic matter is predominantly terrestrial and mainly composed of phytoclasts and sporomorphs, together with a relatively abundant gonyaulacoid dinoflagellate cysts. Taxa include the dinoflagellate cysts Achomosphaera alcicornu, Operculodonium centrocarpum, Spiniferites mirabilis, Polysphaeridium zoharyi and Spiniferites ramosus. Angiosperms include Bombacacidites nacimientoensis (Bombacoidea), Crototricolpites finitus (Euphorbiaceae?), Echiperiporites estelae (Malvaceae), Lanagiopollis crassa (Pelliciera), Perisyncolporites pokornyi (Malpighiaceae) and the less abundant Clavainaperturites microclavatus (Hedyosmum). Fern spores include Polypodiaceoisporites? fossulatus (Pteridaceae), Polypodiaceoisporites pseudopsilatus, Echinatisporis muelleri, Striatriletes saccolomoides and Concavissimisporites fossulatus.

The common presence of $C$. microclavatus indicates that the age of both samples is younger than Early Miocene, according to its widespread Neogene fossil record in the Neotropics Graham, 1985; Hoorn, 1994; Van Der Hammen and Hooghiemstra, 2000; da Silva-Caminha, et al., 2010; Jaramillo et al., 2011; Martínez et al., 2013), its oldest palynological records from Central (10.2 Ma) and South America (21.5 Ma; Martínez et al., 2013), and the palynological zonation of Jaramillo et al. (2011).

Mollusks associated with this section (STRI localities 290950 and 640015) - Leopecten sp.,Crassostrea sp., Ampullinopsis spenceri, Galeodea sp. and Ficus cf. F. carbasea and gastropod fossils of Naticidae, Mu- ricidae, Antillophos aff. A. gatunensis, Conus sp., and Turridae - are similar to other faunas in Miocene strata from Panamá (e.g., Culebra, Galique, Gatun and Chucunaque formations; Hendy, 2013). The presence of Ampullinopsis spenceri in the lower part of the succession indicates an Early Miocene (Aquitanian - Burdigalian) age. Based on the data, we assign an Early Miocene age (Burdigalian?) to the sedimentary sequence in the Torio Beach (Figure 1).

\subsection{SYSTEMATICS}

Here we present a revision of the fossil genus $\mathrm{La}^{-}$ cunofructus. The exquisite preservation of the new fossils, from the Oligocene and the Early Miocene localities, allows us to observe the cellular structure of the endocarp and seed that was not present in the original material described by Herrera et al. (2012).

Family Humiriaceae Jussieu

Genus Lacunofructus Herrera, Manchester et Jaramillo, here emended.

Emended generic diagnosis. Endocarp tri to hexa-carpellate with three to six valves and septa. Valves conspicuous. Seeds one per locule. Small cavities abundant within valves or septa. The endocarp wall and septa are composed of clusters of interlocked and elongated sclereids. Two cotyledons. Endosperm composed of anticlinal cells, approximately isodiametric and hexagonal in outline. The hypocotyl is composed of approximately isodiametric and hexagonalto pentagonal cells in outline.

Type species. Lacunofructus cuatrecasana Herrera, Manchester et Jaramillo (Figures 3A to 3J).

Description. Endocarp elliptic to ovate (figures 3A, 3C, 3D and 3K). Length 8.3 to $21.6 \mathrm{~mm}$, width 16.3 to $8.1 \mathrm{~mm}(\mathrm{n}=12)$. Surface smooth. Apex rounded to elliptic (Figure 3B), base rounded to elliptic. Septa and valves three to five, radially arranged. Septa enlarging outward, as seen in transverse section (figures 3F, 3I and 3J). Valves 


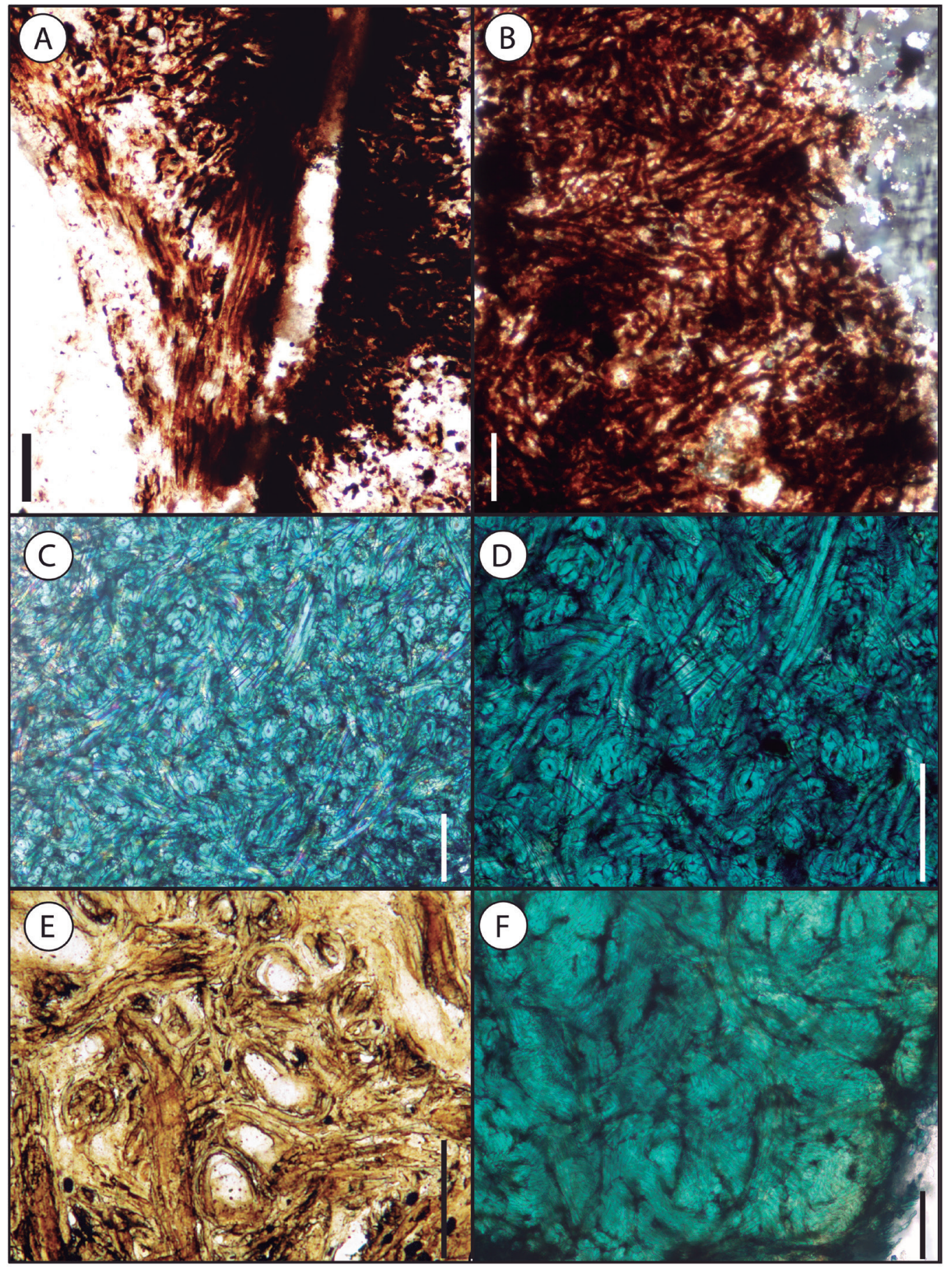

Figure 4 A - B, Lacunofructus cuatrecasana from the western Azuero Peninsula. Specimen FMNH 68987-STRI40033 (Early Miocene). A, Acetate peel of the endocarp; note elongated cells.

$B$, Acetate peel of the endocarp; note elongated sclereids cells in longitudinal section forming a twisted network.

C - D, Extant Vantanea depleta. Specimen SCZ-15737.

C, Thin section showing endocarp wall cells.

D, Detail of 4-C (Vantanea depleta).

E, Acetate peel of Vantanea depleta from the Oligocene of Perú. Elongate and twisted fibers forming a messy network. Image from Manchester et al. (2012).

F, Extant Humiriastrum diguense. Specimen SCZ-15724. Thin section of the endocarp showing elongated cells. Scale bar: $100 \mu \mathrm{m}$. 
conspicuous, without a median furrow on the surface, lingulate to elliptic (figures $3 \mathrm{~A}, 3 \mathrm{C}$ and $3 \mathrm{D}$ ), running lengthwise, but without reaching fully to the apex or the base of the endocarp (Figure 3B). Seeds one per locule. Up to four locules per specimen; pentagonal to ovate as viewed in transverse section (figures 3E, 3F and 3G). Endocarp without apical foramina. Small ellipsoidal to circular cavities present and abundant in the endocarp wall and septa, ranging from 0.1 to $0.4 \mathrm{~mm}$ in diameter (figures 3H, 3J and 3L). Vascular strand at the central axis of the endocarp (Figure 3E).

The endocarp wall and septa are composed of elongate sclereids 5.4 to $13.2 \mu \mathrm{m}$ in width (figures 4A and 4B). Endocarp cells are arranged in clusters of interlocked and elongate sclereids with very high density, giving the endocarps a woodylike texture (Figure 4). Two cotyledons (Figure 5A). Endosperm composed of anticlinal cells, approximately isodiametric and hexagonal in outline, that vary from 0.029 to $0.070 \mu \mathrm{m}$ in diameter (figures 5B and 5C). Endosperm cells are arranged in lines radiating from the cotyledons or hypocotyl in cross section (figures $5 \mathrm{~B}$ and $5 \mathrm{C}$ ). The hypocotyl is composed of approximately isodiametric hexagonal to pentagonal cells that vary from 0.017 to $0.037 \mu \mathrm{m}$. The fossil seeds of Lacunofructus cuatrecasana show a high embryo-to-seed ratio $(\mathrm{E}: \mathrm{S})$ and thin, leafy cotyledons (figures 5A, 5B and 5D).

Specimens. These are preserved as both carbonizations (FMNH 68988-STRI 38782 [Early Miocene], FMNH 68986-STRI 40034 [Early Miocene], FMNH 68981-STRI 40052[Early Miocene], FMNH 68983-STRI 38784 [Oligocene], FMNH 68984-STRI 40032 [Oligocene], and FMNH 68985-STRI 40047 [Oligocene]) and calcite permineralizations (FMNH 68982STRI40060 [Early Miocene] and FMNH $68987-$ STRI 40033 [Early Miocene]).

New occurrence. Location: Panamá, west Azuero Peninsula (STRI 640015: 7.54510 N, -80.95070 W; STRI 990406: 7.54500 N, -80.94980 W; STRI 990413: $7.63920 \mathrm{~N},-80.93310 \mathrm{~W}$ ).

Age and formation. Locality 990413 corresponds to the Oligocene. Rocks belong to an un- described geological formation. Localities 640015 and 990406 correspond to the Early Miocene Tonosí Fm. (?)

Affinity. Fruits of Humiriaceae have woody endocarps with a central vascular axis, up to 10 carpels, one or two seeds per locule, and are easily recognizable by their distinctive dorsal germination valves (Herrera et al., 2010). No other family among flowering plants has this set of characters. Lacunofructus cuatrecasana preserves the combination of characters diagnostic of Humiriaceae.

Lacunofructus is a fossil genus first described from the Eocene of the Tonosi Formation in the Azuero Peninsula (Herrera et al., 2012). The new specimens of Lacunofructus are similar in endocarp structure and anatomy to the extant species analyzed in this study (i.e., Vantanea depleta [figures 4C and 4D], Sacoglottis ovicarpa [Figure 6D], and Humiriastrum diguense [Figure 4F]). The same anatomical details of the endocarp have been reported for Vantanea cipaconensis from the Oligocene of Perú (Figure 4E) (Manchester et al., 2012). Among extant Humiriaceae, Lacunofructus resembles Vantaneain terms of fruit and seed anatomy. The major difference between these two genera is that Vantanea do not have endocarp wall cavities (Herrera et al., 2010).

\section{cf. Sacoglottis sp.}

Description. FMNH 68979-STRI 38790 and FMNH 68980-STRI 40059. The fossils FMNH 68979-STRI 38790 is a longitudinal section of an endocarp showing two lateral valves and a central seed cavity (Figure 6A), while FMNH 68980-STRI 40059 appears to be an isolated valve. Lacunae diameter ranges from 1 to $4.7 \mathrm{~mm}$. Specific characters such as the number of valves, the shape of the endocarp, or the number of seeds per locule could not be determined. The cells of the endocarp form a twisted and interlocked network, giving the endocarps a woody-like texture and measure 7 $30 \mu \mathrm{m}$ in width (Figure 6B).

Systematic affinity. The new fossil material shows the closest similarity to living genus Sacoglottis. Species of Sacoglottis are recognized by abun- 


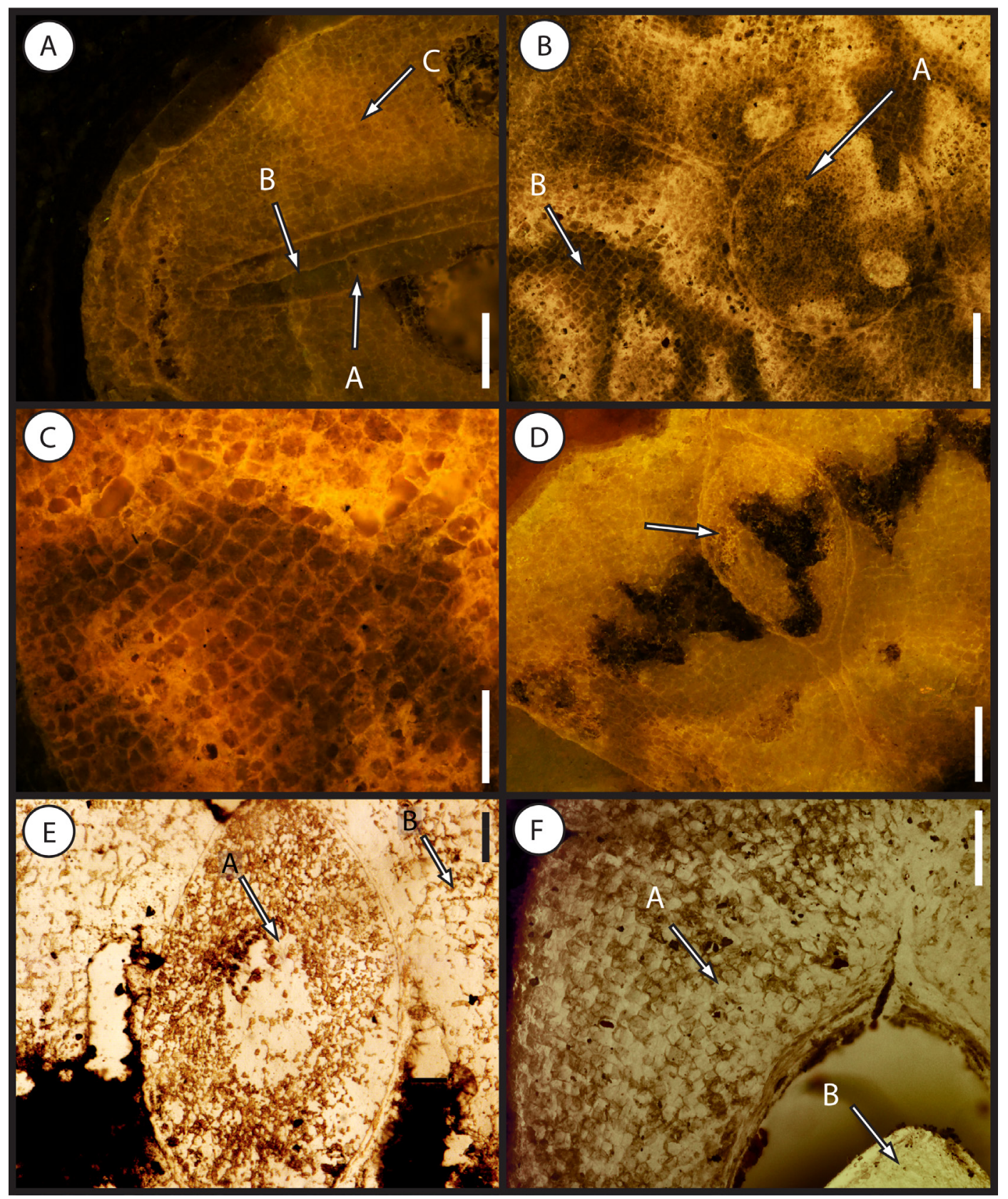

Figure 5 A - E, Epifluorescence images of seeds of Lacunofructus cuatrecasana.

A - D, Specimen FMNH 68982-STRI40060-11 (Early Miocene).

A, Transverse section of the upper half part of a seed showing two cotyledons (arrow A) divided by a midline (arrow B) and abundant endosperm tissue (arrow C).

B, Transversal section of the lower half part of the seed showing the circular hypocotyl (arrow A) and endosperm tissue (arrow B).

C, Detail of the endosperm cells of the seed, anticlinal cells, approximately isodiametric and hexagonal in outline.

D, Transversal section of the lower half part of a seed showing the oval hypocotyl.

E, Acetate peel showing oval hypocotyl, hypocotyl cells (arrow A), and endosperm cells (arrow B).

F, Extant Sacoglottis ovicarpa. Specimen SCZ-1296. Epifluorescence image of transversal section of the lower half part of the seed, showing abundant endosperm tissue (arrow A) and circular hypocotyl (arrow B).

Scale bar: A, B, D, F: $0.3 \mathrm{~mm}$; C, E: $0.1 \mathrm{~mm}$. 
dant lacunae or oil-filled cavities in the endocarp wall (Figure 6C) and variable drupe morphology (i.e., ovoid, globose, oblong and elliptic). The number of valves in Sacoglottis endocarps is typically 5 , but sometimes the endocarps contain only 3 or 4 valves, which vary from long, elliptical to broad in shape. The valves are inconspicuous and the septa narrow outwards (Figure 6C).

Specimens. FMNH 68983-STRI 38784, FMNH 68984-STRI 40032, FMNH 68986-STRI 40034, FMNH 68987-STRI 40033, FMNH 68981-STRI 40052, and FMNH 68982-STRI 40060.
New occurrence. Location: Panamá, west Azuero Peninsula (STRI 640015: 7.54510 N, -80.95070 W; STRI 990406: 7.54500 N, -80.94980 W). Age and formation: Early Miocene Tonosí Fm.?

\subsection{EXTANT FRUITS}

The anatomical study of extant Humiriastrum diguense, Vantanea depleta and Sacoglottis ovicarpa shows that the endocarp walls are mostly composed of clusters of sclereids and fiber tracts (figures 4 and 6). The transverse diameter of these cells varies in

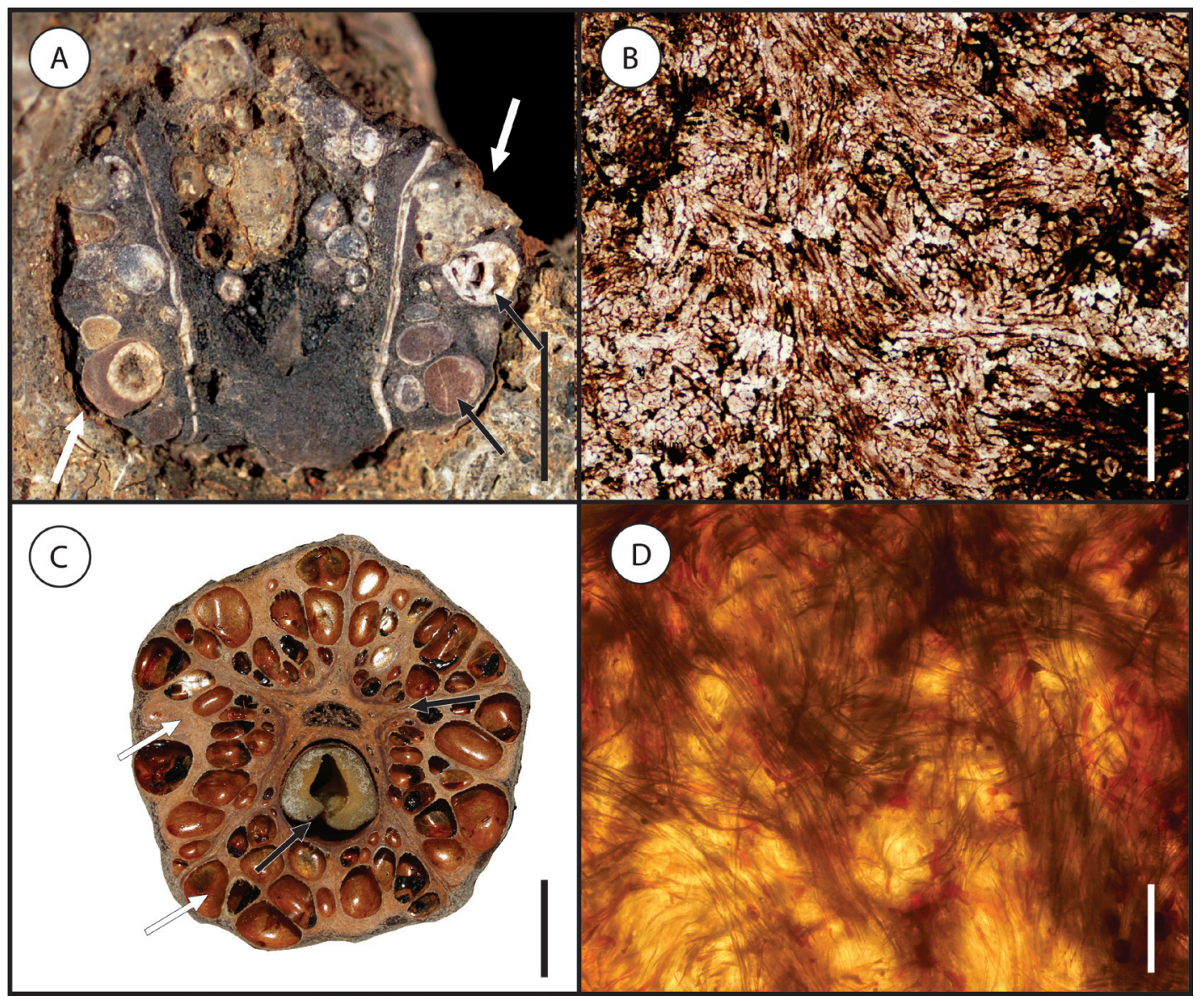

Figure 6 A - B, c.f. Sacoglottis, specimen FMNH 68979-STRI38790 (Early Miocene).

A, Longitudinal section of endocarp showing two valves (white arrows) and abundant lacunae (black arrow).

$B$, Acetate peel of endocarp showing cellular structure. Abundant sclereids are visible and form a twisted and interlocked network, giving the endocarps a woody-like texture.

C - D, Sacoglottis ovicarpa from Panamá, specimen SCZ-1296 of Herrera et al. (2010).

C, Transverse section of endocarp showing five valves (white arrow), septae (black arrow), abundant lacunae (lower white arrow), and seed locule (lower black arrow).

$D$, Thin section of the endocarp showing elongated sclereids in a messy and twisted network.

Scale bar: A, C: 1cm; B, D: $10 \mu \mathrm{m}$. 
Humiriastrum diguense from 5.4- $14.9 \mu \mathrm{m}$ (Figure 4), in Vantanea depleta from 7.4 - 40.1 $\mu \mathrm{m}$ (Figure 4), and in Sacoglottis ovicarpa from $7-30 \mu \mathrm{m}$ (Figure 6).

\section{Discussion}

\subsection{SEDIMENTOLOGY}

Both the Torio Beach (Early Miocene) and Palo Seco River (Oligocene) sequences start with a basal conglomerate, suggesting important input from continental terrains. Furthermore, algal reefs, fragments of corals, shells, echinoids, burrows and talassinoids found in the Torio Beach deposits, as well as the presence of fossil seeds, wood and continental palynomorphs from the palynological analysis (e.g., phytoclasts and sporomorphs), suggest a shallow-marine reefal environment with contributions of continental fluvial systems.

The facies associations of the sequence measured in Palo Seco River suggest that these sediments were deposited in a shallow-marine setting with an important clastic input from a continental fluvial environment. The presence of fossil mollusks, crabs, and traces of foraminifera in the calcareous sublitharenites support a shallow-marine environment, and the fossil seeds, leaves, and wood suggest a contribution from continental fluvial environments. Overall, the sedimentology of these localities suggests the exhumation of terranes in the western Azuero Peninsula at least since the Oligocene, which contrasts with earlier exhumation phases recorded in shallow marine to transitional environments in the southern Azuero Peninsula (Tonosí Fm; Herrera et al., 2012).

\subsection{PALEOBIOGEOGRAPHICAL IMPLICATIONS}

Paleobotanical and palynological studies have shown that at least since the Early Miocene $(\sim 20$ $\mathrm{Ma})$, the Panamanian forests were already dominated by Gondwana-Amazonian taxa. This floristic composition suggests that dispersal events from South America into Central America were likely much more common than from North Ameri- ca (Jaramillo et al., 2014). Humiriaceae probably originated in the Neotropics; however, it is still unknown whether the origin was in Central or South America. The Humiriaceae fossils presented in this study, together with the sedimentology of the fossil localities, indicate that Humiriaceae rapidly colonized newly formed landscapes at least since the Oligocene and Early Miocene on the western Azuero Peninsula.

The new records of Lacunofructus also expand the temporal and paleogeographical range of the fossil genus. Lacunofructus was initially described from the Late Eocene of the southern Azuero Peninsulaas the oldest record of the family Humiriaceae (Herrera et al., 2012), suggesting that Lacunofructus likely originated in ancestral Central America. The occurrence of Lacunofructus in these new localities indicates that the genus persisted in Central America at least until the Early Miocene.

The fossils identified in this work as cf. Sacoglottis sp. from the Early Miocene of the western Azuero Peninsula also expand the geographical range of the genus in Central America, showing that this genus was an early component of Central American tropical forests. Sacoglottis fossils are common in several other localities from both southern Central America and northern South America, which suggests that plant dispersal events in between these regions took place long before the final closure of the Central America Seaway (Jaramillo et al., 2014). The oldest record of this genus comes from the Oligocene of Puerto Rico in Central America (Herrera et al., 2014b). Early - Middle Miocene Sacoglottis fossils have also been studied from the Cucaracha Fm. in the Panamá Canal (Herrera et al., 2010), Middle - Late Miocene to Pliocene in the High Plain of Bogota (Wijninga and Kuhry, 1990), and the Pleistocene of Puerto Rico (Lott et al., 2011).

The sedimentology and stratigraphy of the studied localities (Figure 2) suggests that the fossil endocarps of Lacunofructus cuatrecasana and cf. Sacoglottis sp. were deposited in shallow marine to transitional environments with an important input of continental organic matter (e.g., seeds, wood, phy- 
toclasts, and sporomorphs). The observed hard and woody endocarps with thick walls, composed of clusters of elongated sclereids forming a mesh (figures 4 and 6), as well as the oil cavities in the endocarp of some species (Cuatrecasas, 1961), allows fruits of Humiriaceae to have high buoyancy and travel long distances in rivers and even in the sea (Gunn and Dennis, 1976). These characteristics could have aided Humiriaceae fruits in the dispersal across the forming landscapes of Central America during the Oligocene and Early Miocene. We note that it is possible that some of the fossils studied here were transported into the depositional site from far away sources and may not represent an autochthonous flora of the Azuero Peninsula during the Oligocene - Miocene. However, the presence of Humiriaceae fossil fruits in other Eocene site (Herrera et al., 2012), and fossil wood from the Oligocene - Miocene (Jud and Dunham, 2017) suggests that these plants were already an important constituent of Panamanian forests by the Eocene - Miocene.

\section{Conclusions}

The new fossil endocarps from the western Azuero Peninsula form a record of the early vegetation that colonized the landscape that formed during the Oligocene and Early Miocene. Lacunofructus cuatrecasana probably originated in Central American forests during the Eocene and was present at least until the Early Miocene. The origin of cf. Sacoglottis sp. is not clear, but it dispersed across both Central and South America during the Miocene. The fossils studied have similar histological characters as modern representatives of the family, which could have aided in their preservation in the fossil record. Fossils where deposited in shallow-marine to transitional environments, indicating the presence of active fluvial systems in newly formed terranes during the Oligocene and Early Miocene.

\section{Acknowledgements}

The Smithsonian Tropical Research Institute Short Term Fellowship to Nicolas Pérez-Consuegra funded part of this project. PCP-PIRE, University of Florida, Universidad de los Andes, and STRI also provided financial and logistical support in the field. We would like to thank the 2014 - 2015 Azuero Field Camp crew and C. Monje for their help in the field and in geological discussions. E. Moreno helped in making the extant fruit sections. S.R. Manchester, N. Jud, C. Martínez, J. Wright, and C. Zalamea helped in discussions regarding the fossil fruits. Jorge Ceballos provided access to the laboratory of fluorescence microscopy. C. Galdamei was especially kind in giving access to the material from the STRI Herbaria. Nicolas Perez thanks A. Cardenas and H. Muller Landau for their revisions of the proposal for the STRI-STF. C. Ortiz is acknowledged for digitalizing the geological map. We also thank Milton and Gustavo Rueda from Paleoflora Inc. (Bucaramanga, Colombia) for processing of samples for palynology. We thank Idael Blanco and Editor Antoni Camprubí, as well as Edwin Cadena and one anonymous reviewer for insightful comments that improved the quality of this article.

\section{References}

Bacon, G.D., Silvestro, D., Jaramillo, C., Smith, B.T., Chakrabarty, P., Antonelli, A., 2015, Biological evidence supports an early and complex emergence of the Isthmus of Panamá: Proceedings of the National Academy of Sciences, 112, 6110-6115.

Bardon, L., Chamagne, J., Dexter, K.G., Sothers, C.A., Prance, G.T., Chave, J., 2013, Origin and evolution of Chrysobalanaceae: Insights into the evolution of plants in the Neotropics: Botanical Journal of the Linnean Society, 171, 19-37. 
Barthlott, W., Kauer, W., Placke, A., 1996, Global distribution of species diversity in vascular plants: towards a world map of phytodiversity: Erdkunde, 50, 317-327.

Berry, E.W., 1924, Fossil Fruits from the Eastern Andes of Colombia: Bulletin of the Torrey Botanical Club, 51, 61.

Bolli, H.M., Saunders, J.B., Perch-Nielson, K., Caron, M., Toumarkine, M., Luterbacher, H., Jenkins, D.G., Laccarino, S., Rogl, F., Remane, J., 1989, Volume 1. Planktic Foraminifera, Calcareous Nannofossils and Calpionellids: CUP Archive.

Bown, P.R., 1998, Calcareous Nannofossil Biostratigraphy: British Micropalaeontological Society Publication Series, Chapman and Hall, Kluwer Academic Publishers, 315 p.

Buchs D.M., Baumgartner P.O., BaumgartnerMora G., Flores K., Bandini A.N., 2011, Upper Cretaceous to Miocene tectonostratigraphy of the Azuero area (Panamá) and the discontinuous accretion and subduction erosion along the Middle American margin: Tectonophysics, 512, 31-46.

Burnham, ,R.J., Graham, A., 1999, The History of Neotropical Vegetation: New Developments and Status: Annals of the Missouri Botanical Garden, 86, 546-589.

Carvalho, M., Londoño, L., Wood, A., Cardenas, A., Escobar, J., Herrera, F., Jaramillo, C., Royer, D.L., 2013, Mummified leaf assemblage provides insight to neotropical forest ecophysiology during the middle miocene climatic optimum, in GSA Annual Meeting in Denver: 125th Anniversary of GSA: Denver, Colorado, The Geological Sociery of America, 186-14.

Cuatrecasas, J., 1961, A Taxonomic Revision of the Humiriaceae: Contributions from the United States National Herbarium, 35, 25-214.

da Silva-Caminha, S.A.F., Jaramillo, C.A., Absy, M.L., 2010, Neogene palynology of the Solimões Basin, Brazilian Amazonia: Palaeontographica, 283, 1-67.

Gradstein, F.M., Ogg, J.G., Schmitz, M.D., Ogg, G.M. (eds), 2012, The Geologic Time Scale: Boston, Elsevier, 1176 p.

Graham, A., 1985, Studies in neotropical paleobotany. IV. The Eocene communities of Panamá: Annals of the Missouri Botanical Garden, 72, 504-534.

Gunn, G.R., Dennis, J.V., 1976, World guide to tropical drift seeds and fruits: New York, Quadrangle/New York Times Book Co., $240 \mathrm{p}$.

Hendy, A.J.W., 2013, Spatial and Stratigraphic Variation of Marine Paleoenvironments in the Middle-Upper Miocene Gatun Formation, Isthmus of Panamá: Palaios, 28, 210-227.

Herrera, F., Manchester, S.R., Jaramillo, C., 2012, Permineralized fruits from the late Eocene of Panamá give clues of the composition of forests established early in the uplift of Central America: Review of Palaeobotany and Palynology, 175, 10-24.

Herrera, F., Manchester, S.R., Jaramillo, C., MacFadden, B., da Silva-Caminha, S.A., 2010, Phytogeographic History and Phylogeny of the Humiriaceae: International Journal of Plant Sciences, 171, 392-408.

Herrera, F., Manchester, S.R., Koll, R., Jaramillo, C., 2014a, Fruits of Oreomunnea (Juglandaceae) in the early Miocene of Panamá, in Stevens, W.D., Montiel, O.M., Raven, P.H. (eds.), Paleobotany and biogeography: A Festschrift for Alan Graham in his 80th year: Monographs in systematic botany from the Missouri Botanical Garden, 128, 124-133.

Herrera, F., Manchester, S.R., Vélez-Juarbe, J., Jaramillo, C., 2014b, Phytogeographic History of the Humiriaceae (Part 2): International Journal of Plant Sciences, 175, 828-840. 
Hoorn, C., 1994, An environmental reconstruction of the paleo-Amazon river system (Middle-Late Miocene, NW, Amazonia): Palaeogeography, Palaeoclimatology, Palaeoecology, 112, 187-238.

Jaramillo, C., 2016, Evolution of the Isthmus of Panamá: biological, paleoceanographic, and paleoclimatological implications, in Hoorn, C., Antonelli, A., (eds.), Mountains, Climate and Biodiversity,. Oxford, John Wiley \& Sons Jaramillo, G., Montes, G., Cardona, A., Silvestro, D., Antonelli, A., Bacon, C.D., 2017, Comment (1) on "Formation of the Isthmus of Panamá" by O'Dea et al:: Science Advances, 3, el602321.

Jaramillo, C., Moreno, E., Ramírez, V., da Silva-Caminha, S.A.F., de la Barrera, A., de la Barrera, A., Sánchez, C., Morón, S., Herrera, F., Escobar, J., Koll, R., Manchester, S.R., Hoyos, N., 2014, Palynological record of the last 20 million years in Panamá, in Stevens, W.D., Montiel, O.M., Raven, P.H. (eds.), Paleobotany and biogeography: A Festschrift for Alan Graham in his $80^{\text {th }}$ year: Monographs in systematic botany from the Missouri Botanical Garden, 128, 134-251.

Jaramillo C., Rueda, M., Torres, V., 2011, A palynological zonation for the Cenozoic of the Llanos and Llanos Foothills of Colombia: Palynology, 35, 46-84.

Joy, K.W., Willis, A.J., Lacey, W.S., 1956, A Rapid Cellulose Peel Technique in Palaeobotany: Annals of Botany, 20, 635-637.

Jud, N.A., Dunham, J.I., 2017, Fossil woods from the Cenozoic of Panamá (Azuero Peninsula) reveal an ancient neotropical rainforest: International Association of Wood Anatomists Journal, 38, 366-S2.

Jud, N.A., Nelson, G.W., 2017, A liana from the lower Miocene of Panamá and the fossil record of Connaraceae: American Journal of Botany, 104, $685-693$.

Jud, N.A., Nelson, C.W., Herrera, F., 2016, Fruits and wood of Parinari from the early Miocene of Panamá and the fossil record of Chrysobalanaceae: American Journal of Botany, 103, 277-289.

Kedenburg, M.D., 2016, Thermochronological constraints on Cenozoic uplift and exhumation of the Azuero Peninsula, Panamá: Implications for south central american stratigraphy and tectonics: Florida, University of Florida, M.S. Thesis,

Kolarsky, R., Mann, P., Monechi, S., 1995, Stratigraphic development of southwestern Panamá as determined from integration of marine seismic data and onshore geology: Geological Society of America Special Papers, 295, 159-200.

Kubitzki, K., 2014, Humiriaceae, in Kubitzki, K., (ed.), The Families and Genera of Vascular Plants, Flowering Plants, Eudicots: Berlin, Springer, 223-228.

Lott, T.A., Dilcher, D.D.L., Horn, S.S.P., Vargas, O., Sanford, R.L.Jr., 2011, Pleistocene flora of Rio Puerto Viejo, Costa Rica: Palaeontologia Electronica, 14, 5A.

MacFadden, B.J., Jones, D.S., Jud, N.A., MorenoBernal, J.W., Morgan, G.S., Portell, R.W., Perez, V.J., Moran, S.M., Wood, A.R., 2017, Integrated chronology, flora and faunas, and paleoecology of the Alajuela Formation, Late Miocene of Panamá: PLOS ONE, 12, e0170300.

Manchester, S.R., Herrera, F., Fourtanier, E., Barron, J., Martínez, J.-N., 2012, Oligocene Age of the Classic Belén Fruit and Seed Assemblage of North Coastal Peru based on Diatom Biostratigraphy: Journal of Geology, 120, 467-476.

Martínez, G., Madriñán, S., Zavada, M., Jaramillo G., 2013, Tracing the fossil pollen record of Hedyosmum (Chloranthaceae), an old lineage with recent Neotropical diversification: Grana, 52, 161-180.

Martini, E., 1971, Standard Tertiary and Quarternary calcareous nannoplankton zonation in Farinacci, A., 1970, Proceedings of the Second Planktonic Conference: Rome, Tecnoscienza, 739-785. 
Montes, C., Bayona, G., Cardona, A., Buchs, D.M., Silva, C.A., Morón, S., Hoyos, N., Ramírez, D.A., Jaramillo, C.A., Valencia, V., 2012a, Arc-continent collision and orocline formation: Closing of the Central American seaway: Journal of Geophysical Research: Solid Earth, 117, B04105.

Montes, C., Cardona, A., McFadden, R., Morón, S.E., Silva, C.A., Restrepo-Moreno, S., Ramírez, D.A., Hoyos, N., Wilson, J., Farris, D., Bayona, G.A., Jaramillo, C.A., Valencia, V., Bryan, J., Flores, J.A., 2012b, Evidence for middle Eocene and younger land emergence in central Panamá: Implications for Isthmus closure: Bulletin of the Geological Society of America, 124, 780-799.

Montes, G., Cardona, A., Jaramillo, C., Pardo, A., Silva, J.C., Valencia, V., Ayala, C., PerezAngel, L.C., Rodriguez-Parra, L.A., Ramirez, V., Nino, H., 2015, Middle Miocene closure of the Central American Seaway: Science, 348, 226-229.

Nelson, C.W., Jud, N.A., 2017, Biogeographic Implications of Mammea paramericana sp. nov. from the Lower Miocene of Panamá and the Evolution of Calophyllaceae: International Journal of Plant Sciences, 178, 241-257.

O’Dea, A., Lessios, H.A., Coates, A.G., Eytan, R.I., Restrepo-Moreno, S.A., Cione, A.L., Collins, L.S., de Queiroz, A., Farris, D.W., Norris, R.D., Stallard, R.F., Woodburne, M.O., Aguilera, O., Aubry, M.-P., Berggren, W.A., Budd, A.F., Cozzuol, M.A., Coppard, S.E., Duque-Caro, H., Finnegan, S., Gasparini, G.M., Grossman, E.L., Johnson, K.G., Keigwin, L.D., Knowlton, N., Leigh, E.G., Leonard-Pingel, J.S., Marko, P.B., Puenson, N.D., Rachello-Dolmen, P.G., Soibelzon, E., Soibelzon, L., Todd, J.A., Vermeij, G.J., Jackson, J.B.C., 2016, Formation of the Isthmus of Panamá: Science Advances, 2, e1600883.

Rodríguez-Reyes, O., Falcon-Lang, H., Gasson, P., Collinson, M., Jaramillo C., 2014,
Fossil woods (Malvaceae) from the lower Miocene (early to mid-Burdigalian) part of the Cucaracha Formation of Panamá (Central America) and their biogeographic implications: Review of Palaeobotany and Palynology, 209, 11-34.

Rodríguez-Reyes, O., Gasson, P., Thornton, C., Falcon-Lang, H.J., Jud, N.A., 2017, Panascleroticoxylon crystallosa gen. et sp. nov.: a new Miocene malpighialean tree from Panamá: International Association of Wood Anatomists Journal, 38, 1-19.

Traverse, A., 2007, Paleopalynology: Netherlands, Springer, $813 \mathrm{p}$.

Van Der Hammen, T., Hooghiemstra, H., 2000, Neogene and Quaternary history of vegetation, climate, and plant diversity in Amazonia: Quaternary Science Reviews, 19, 725-742.

Wijninga, V.M., 1996a, Neogene ecology of the Salto de Tequendama site $(2475 \mathrm{~m}$ altitude, Cordillera Oriental, Colombia): the paleobotanical record of montane and lowland forests: Review of Palaeobotany and Palynology, 92, 97-156.

Wijninga, V.M., 1996b, Palynology and paleobotany of the Early Pliocene section Río Frío 17 (Cordillera Oriental, Colombia): biostratigraphical and chronostratigraphical implications: Review of Palaeobotany and Palynology, 92, 329-350.

Wijninga, V.M., Kuhry, P., 1990, A Pliocene Flora From the Subachoque Valley (Cordillera Oriental, Colombia): Review of Palaeobotany and Palynology, 62, 249-290.

Williams, G.L., Brinkhuis, H., Pearce, M.A., Fensome, R.A., Weegink, J.W., 2004, Southern Ocean and global dinoflagellate cyst events compared: Index events for the Late Cretaceous-Neogene: Proceedings of the Ocean Drilling Program, Scientific Results, 189, 1-98. 